\title{
ASSINATURAS URBANAS. UM ENSAIO ETNOGRÁFICO SOBRE AS INSCRIÇÕES PÚBLICAS DE PORTO ALEGRE. ${ }^{1}$
}

\author{
Fabrício Silveira \\ Ana Luiza Carvalho da Rocha (Orientação)
}

\section{Um contexto}

$\mathrm{O}$ século XX ainda não havia terminado integralmente e o historiador Nicolau Sevcenko já lhe dedicava um réquiem de rara sobriedade. Como num acerto de contas, o livro em questão, A Corrida para o Século XXI, encerrava-se esperançoso, embora transcorresse amargo. Tentando livrar-se logo do cadáver, entendê-lo e celebrá-lo, como pediriam os ritos da ocasião, aquela ansiosa e um tanto apressada homenagem póstuma oferecia-nos uma poderosa síntese dos cem anos que então se encerravam: atravessar as dez últimas décadas havia sido como passear numa montanha-russa. Na margem do novo milênio, pois um outro milênio ali também se anunciava, nos encontraríamos assim: atônitos, suspensos no ar, tragados por um novo loop. Aguarda-nos, escrevia Sevcenko (2001: 16), “a síncope final e definitiva, o clímax da aceleração precipitada, sob cuja velocidade extrema relaxamos nosso impulso de reagir, entregando os pontos entorpecidos".

Tendo-se ido, o século que confirmou entre nós a ascensão da cultura da imagem e da sociedade de consumo, que nos abandonou à desregulamentação neoliberal dos mercados, o século que nos fez assistir à progressiva retração (a quase acovardada retração) do Estado-

Nação e que distinguiu-se sobretudo pela tendência da acelerada mudança tecnológica (cujos efeitos, aliás, multiplicaram-se e fizeram-se sentir em praticamente todos os campos da atividade humana) só poderia nos deixar um tanto assustados. Além de extenuados, é claro. Agora, na vertigem do loop, uma questão nos escapava: mais exatamente, o que nos espera? Para quê e como devemos então nos preparar?

Sem dúvida, o texto de Sevcenko impregnava-se de severidade. Com os olhos igualmente lançados no futuro, acreditava que somente uma dose justa de engajamento reflexivo pudesse responder ao balanço e aos desfortúnios do século. "Neste momento tumultuoso, em que a celeridade das mudanças vem sufocando a reflexão e o diálogo, mais do que nunca é imperativo investir em funções judiciosas, corretivas e orientadoras da crítica" (SEVCENKO, 2001: 19). 
Entretanto, reconhecia o autor, as décadas recentes nos haviam deixado também algumas expectativas mais reconfortantes. Se as transformações nos atordoavam, se agora nos encontrávamos presos e imobilizados (qual será o desfecho disso tudo?) no loop da montanha russa, gestavam-se, em contraponto, naquele mesmo momento, indícios de melhor agouro. Apesar de tudo, bons prenúncios germinavam naquele desabalado percurso. Dentre eles, talvez o mais vistoso - ao menos no que diz respeito aos interesses da proposição aqui em curso -, fosse a paradoxal revitalização do espaço público. Na virada do século XXI, Sevcenko deparava-se com uma nova ética e uma nova estética em elaboração nas ruas dos grandes centros metropolitanos. "Alguém diria que o front político retornaria para as ruas, tal como na pólis da Grécia antiga?", surpreendia-se ele. Dignos de nota e de apreço pareceramlhe os movimentos sociais e a ampla fauna de refuseniks que se erguiam (e ainda hoje se erguem) em oposição à "síndrome do pensamento único" que acometera as últimas folhas do calendário.

Em livro igualmente recente, mas consideravelmente mais badalado (tão badalado quanto inconformista e até panfletário), a jornalista Naomi Klein também se referiu às associações entre DJs, militantes anticorporações, artistas políticos e ecologistas radicais que bem podem configurar, segundo ela, "o movimento político mais vibrante e de mais rápido crescimento desde 68 em Paris” (2003: 340). Reclaim the Streets (Resgate as Ruas) não é só um lema ou uma inscrição numa bandeira, mas a própria alcunha midiática com a qual tais movimentos sociais, contra-hegemônicos ou anti-globalização, como são ditos, vêm se apresentando e ocorrendo em algumas das grandes metrópoles mundiais, desde meados dos anos 90. Decididamente, a despeito da representatividade e da legitimidade pontuais atribuídas às fontes citadas - de toda forma, diagnósticos semelhantes não seriam tão infreqüentes nem tão infundados na bibliografia sociológica recente ${ }^{2}-$, a ocupação da arena urbana parece recolocar-se em pauta.

Tendo figurado como um dos nódulos temáticos embrionários (e propulsores, como não!) das Ciências Sociais - pois, ao longo do século XIX, hoje já tão distante, o fenômeno urbano passara a exigir a elaboração de um quadro disciplinar consistente, capaz de lhe dar cabo e de bem reconhecer suas implicações e especificidades -, a discussão sobre a cidade culminou, muito modelarmente, nos achados eternizados de Georg Simmel, Walter Benjamin e da Escola de Chicago (Robert Park e cia.). Hoje, cerca de oito décadas depois, podemos apresentá-los, sem dúvida alguma, como aqueles que fundaram e circunscreveram uma sociologia urbana emblematicamente moderna. 
Nos últimos tempos, contudo - e daí também o interesse pelo comentário inaugural de Sevcenko -, a vida metropolitana tout court parecia ter abandonado a categoria de uma temática nobre, dotada ainda de suficiente força impulsionadora no universo sociológico. Parecia encontrar-se um tanto em desuso, um pouco fora de moda (perdoem a força de expressão), um tanto desencantada aos olhos dos sociólogos. A despeito das investidas já maduras (para não dizermos já quase trintonas) de Manuel Castells e Richard Sennett - dois exemplos vigorosos -, a cidade encontrava-se um tanto estigmatizada. Recaia sobre ela o descrédito de uma grande e estrondosa falência. A experiência urbana contemporânea estava a implicar quase sempre suburbanização, delinquiência, poluição... E megacongestionamentos, não é mesmo? O debate acadêmico sobre a cidade fora tomado de assalto pelas temáticas (contíguas, diga-se bem; mas enfim ofuscantes) da globalização, dos alastramentos mercadológicos e dos avanços tecnológicos, justamente aqueles temas que vão, pouco a pouco - segundo Sevcenko, ainda -, demandando a maior parte de nossos esforços especulativos. $\mathrm{Na}$ medida em que o século avançava (ou findava, enlouquecendo e enlouquecendo-nos), surgiam em cena, mais e mais fortemente, os trabalhos sobre a pósmetrópole, conforme a expressão corrente de Edward Soja, sobre a cidade virtual, a cibercidade, como é habitual no linguajar do brasileiro André Lemos ou entre aqueles atentos às reconfigurações do social acarretadas pelas info/teletecnologias, sobre desterritorialização e os novos glocalismos, nos casos mais significativos de Renato Ortiz e Néstor Garcia Canclini, por suposto.

Quase totalmente reconfigurada pelo aparato técnico e pelo capital aparatado, fulcros reincidentes das transformações processadas em nossa morada - aliás, desde sempre -, a moderna experiência urbana encontrava-se um tanto a reboque de tais discussões, que se autoimpunham como mais desafiadoras e urgentes. $^{2}$ Numa imprevisível sequiência de altos e baixos, na oscilação entre um certo (talvez tímido) obscurecimento e uma nova reaparição potencializada - no loop da montanha russa -, a temática urbana outra vez se coloca. Porém, outro viço a justifica.

\footnotetext{
${ }^{2}$ Mesmo Marshall Berman, no hoje clássico Tudo que É Sólido Desmancha no Ar, refere ao embate entre o que chama de 'o modelo da via expressa' e o 'modelo do grito na rua'. Segundo ele, assim se emblematizariam, a partir da cidade de Nova Iorque, que lhe é tão cara, certas configurações de nossa modernidade. É sintomático (e, para nós, bastante ilustrativo) que justamente em torno da ocupação do espaço urbano (enquanto espaço cultural e político) esteja o núcleo do debate. Cf. BERMAN, 1986, p.271-330.
} 
Inserido no campo temático aqui delineado - a área tensa de uma sociologia urbana refeita e reatualizada (ou reatualizando-se, constantemente) -, o presente artigo quer voltar-se exclusivamente à dimensão semiótico-comunicacional da ocupação da arena pública. No interior do quadro macro-sociológico contemporâneo, onde a metrópole parece revigorar-se enquanto ambiência política, ${ }^{3}$ interessa apreender a cidade de Porto Alegre - anunciada desde já como nosso efetivo terreno empírico - como o tecido onde se inscrevem determinadas disputas simbólicas e/ou, talvez mais propriamente, disputas políticas ${ }^{3}$ materializadas numa diversidade enorme de inscrições públicas.

Embora afins - e correlacionáveis, em fácil medida -, as ênfases que procuraremos aqui obter são diversas daquelas alcançadas por Nicolau Sevcenko e Naomi Klein, que nos serviram, sobretudo, para introduzir uma tematização genérica e, dentro dela, afirmarmos nossas especificações de trabalho e nossos viéses analíticos de formação. Ainda que não nos interesse agora sustentar o enquadramento histórico e o exato foco sócio-político com o qual opera Sevcenko, ainda que não nos caiba também compactuar integralmente com o encaminhamento e as tonalidades dados ao tema por Naomi Klein, parece válido recorrer a eles na medida em que permitem apresentar a questão como um 'signo dos tempos', como um 'índice de época'.

Em nosso caso, mais restritivamente, trata-se de tentar perceber o engendramento de um embate por espaços e por visibilidades públicas na capital gaúcha. Interessam-nos os modos de apropriação semiótica da paisagem urbana - e há modo mais efetivo de apropriar-se de algo do que demarcá-lo, inscrever nele - no objeto da posse - o nome do possuidor? Porto Alegre passará a ser vista como uma superfície expressiva na qual se projetam e se materializam diferentes assinaturas.

Como supomos, tais assinaturas pertencem 1) ao mundo e à lógica do mercado, como manifestado numa considerável e evidente diversidade de marcas, logotipos e outdoors, entre outras estratégias de anunciabilidade publicitária que povoam nossa rotina urbana.

3 “Quando falamos aqui do caráter 'político' dessas lutas, não o fazemos no sentido restrito das demandas que se situam no âmbito dos partidos e do Estado. Estamos nos referindo a um tipo de ação cujo objetivo é a transformação de uma relação social que constrói os sujeitos numa relação de subordinação". O argumento acima, empregado por John Downing e Laura Stein no livro Mídia Radical (2002: 406), ajuda-nos a tangenciar o debate eminentemente político (ou político-partidário, político-institucional, etc), recortando melhor nosso foco de atuação: interessam-nos as micro-políticas e aquilo que Michel de Certeau chamou de "astúcias" e "estratégias dos fracos", encontradas no cotidiano miúdo e na experiência banal do vivido. É a essas 'confrontações' (entre 'mundos formalizados' e 'informalizados', entre mundos 'instituídos', 'mal-instituídos' e 'não-instituídos') que estamos aludindo quando mencionamos a ocorrência de 'disputas políticas'. Salientamos ainda que nosso movimento (teórico-temático) se dá no plano dos sentidos e das significações sociais (daí a atenção pontual nas linguagens urbanas). 
"Até há décadas", impressiona-se Canclini (2003: 160), tendo uma gigantesca Cidade do México diante dos olhos, "as imagens emblemáticas das megalópoles eram as chaminés das fábricas e as vilas operárias, hoje são os enormes painéis da publicidade transnacional que saturam até a poluição visual todas as vias expressas". Contudo, tais codificações metropolitanas não são apenas índices de mercantilização da visualidade urbana, mas pertencem também 2) ao mundo e à lógica da sociedade civil, dos movimentos sociais e dos atores sociais 'desinstitucionalizados', representando (e munidos unicamente de) suas idiossincráticas convicções políticas, seus interesses programáticos e suas necessidades de realização estética, inclusive - de sua libido expressiva, enfim -, de onde ganham vazão toda sorte de grafites, pichações e intervenções urbanas (détournement ou culture-jamming 4 , nos informa Naomi Klein; ou 'textos de resistência', como fala Michel de Certeau [2000]). Tais marcações de uma cidade são dadas ainda 3) pelo mundo das ordens e dos regramentos institucionais, pelo mundo da gestão (ou das tentativas e dos esforços já tão precarizados de gestão) do Estado, em função do qual acomodam-se placas de sinalização de trânsito, monumentos históricos, mobiliário urbano, etc.

Gostaríamos assim de cartografar qualitativamente, em função de alguns poucos casos suficientemente representativos - suficientemente "bons para pensar" -, estas disputas simbólicas, o ombro a ombro dos discursos públicos, o conflito das assinaturas no caótico e acidentado tecido urbano. Seria estimulante tentar perceber então coexistências, justaposições ou canibalizações desses discursos (e/ou desses interesses) antagônicos grafados no espaço público. Como estas inscrições diversas demarcam posições? Associam-se de algum modo, talvez por contigüidade, talvez por inter-referência? Por certo, sabotam-se. Mas como? Por pilhagem de espaços formais conquistados, pelo carregamento neo-barroco de grafismos em mútua anulação ou pelo seqüestro das margens da identificação expressiva, numa mestiçagem generalizadamente diluidora? Que recursos textuais mobilizam no intuito de se afirmarem perante os olhares e os fluxos citadinos? Assim, interessa mapear os desagravos e os embates semio-políticos dos códigos, a conflituosa semiodiversidade das inscrições urbanas. Reclaim the streets ao nosso modo. Como decorrência, a própria sociabilidade proporcionada por uma cidade povoada de codificações em luta se colocará também no horizonte do debate.

4 Détournement e culture-jamming são formas de desfiguração e sabotagem de outdoors e anúncios publicitários. Obviamente, trata-se de subverter o sentido original. Segundo Naomi Klein (2003: 308), "as ruas são espaços públicos (...), e uma vez que a maioria dos moradores não pode fazer frente às mensagens corporativas comprando suas próprias peças publicitárias, eles devem ter o direito de responder às imagens que nunca pediram para ver". 


\title{
2. Considerações metodológicas
}

Dadas as questões levantadas e a natureza fragmentária de nosso objeto, considerados também o recorte analítico e o espírito (ou o hábito) investigativo com o qual pretendemos encará-lo, determinados procedimentos etnográficos nos pareceram os procedimentos metodológicos mais adequados. Assim, a etnografia não estará sendo tomada aqui sem consideráveis reordenações ou adaptações em relação ao que entendemos como o emprego canônico do método. Primeiramente, não se trata de implementar uma etnografia imersionista (como no clássico modelo malinowskiano). Em seguida, assumimos, fundamentalmente, a necessidade da 'provocação de um estranhamento' - os cenários e a paisagem habituais da cidade, com os quais nos defrontamos cotidianamente, só alçariam-se à condição de objetos epistêmicos quando 'destacados' e submetidos a um certo 'isolamento' interpretativo. Além de não configurar uma heresia metodológica dentro da própria antropologia, tal ‘desnaturalização' - o estranhamento provocado daquilo que é próximo e familiar assemelha-se inclusive a certos procedimentos heurísticos e estéticos empregados já no final dos anos vinte pelos surrealistas franceses, como sabemos ${ }^{5}$. Estaremos então, conforme as antropólogas Cornelia Eckert e Ana Luiza Carvalho da Rocha, diante da possibilidade de implementação de uma 'etnografia na rua'. Dizem elas:

\begin{abstract}
Através da técnica da etnografia de rua (...) o antropólogo observa a cidade como objeto temporal, lugar de trajetos e percursos sobrepostos, urdidos numa trama de ações cotidianas. Percorrer as paisagens que conformam um território, seguir os itinerários dos habitantes, reconhecer os trajetos, interrogar-se sobre os espaços evitados, é evocar as origens do próprio movimento temporal desta paisagem urbana no espaço. Mas para se apreender a cidade como matéria moldada pelas trajetórias humanas, e não apenas como mero traçado do deslocamento indiferente de um corpo no espaço, o antropólogo precisa recompor os traços aí deixados por homens e mulheres. Uma etnografia de rua não se sustenta como prática antropológica de investigação sem contemplar, desde seu interior, uma reflexão sobre o forte componente narrativo que encerra os deslocamentos humanos (Cornélia Eckert e Ana Luiza Carvalho da Rocha, 2002).
\end{abstract}

Tecnicamente, tais procedimentos etnográficos serão implementados, sobretudo, na recorrência às fotografias dos cenários selecionados. Além disso, os cenários que imaginamos poder destacar serão descritos também textualmente, no recurso aos diários de observação empírica. Tais descrições serão sobre-referendadas ou atestadas pela exposição das fotografias relativas.

\footnotetext{
${ }^{5} \mathrm{Na}$ época, o mesmo procedimento afirmava-se ainda em outros campos da produção cultural. Entretanto, distintos foram os modos de nomeá-lo, construí-lo e aplicá-lo teoricamente. Lucrécia Ferrara (2002: 59) nos lembra que, já em 1916, Viktor Chklovski, no âmbito do formalismo russo, propôs a teoria do estranhamento, num célebre ensaio chamado 'A arte como procedimento'. Mais tarde, por volta de 1935/36, Brecht retomou o conceito, rebatizando-o de afastamento e atribuindo-lhe outras funções: teatral e política. Sintonizado ao ‘espírito de seu tempo', o próprio Walter Benjamin também se interessou por tal 'atitude' intelectual.
} 
Espera-se que tais fotos possam funcionar - tendo em vista o cuidado com "o forte componente narrativo que encerra os deslocamentos humanos" e o acúmulo dos choques perceptivos que caracterizam a experiência urbana, desde Benjamin - como evidenciação e afirmação, num outro plano significante, das descrições feitas e, simultaneamente, como insumos para a interpretação dos sentidos culturais prementes aos cenários eleitos. As fotografias atuarão tanto no plano descritivo ${ }^{6}$, como técnica de exposição fiel e circunstanciada, quanto no plano interpretativo, como deflagração ou mesmo como provocação e motor das análises.

Dito isso, vale salientar que, ao longo do primeiro semestre de 2004, tomamos o centro de Porto Alegre como a região prioritária das observações. Entretanto, por que priorizar afinal o centro da cidade? Tão somente porque supomos que o centro da cidade ocupa lugar de destaque na memória sentimental e no imaginário afetivo de Porto Alegre. De certa forma, os porto-alegrenses encontram-se ainda presos a um certo 'simbolismo do centro'.

"Diferenciando-se de outras cidades como São Paulo e Rio de Janeiro, o crescimento urbano de Porto Alegre não alterou a importância da antiga imagem insular atribuída à área portuária no teatro da vida social", diz a antropóloga Ana Luiza Carvalho da Rocha (in Brandão e Mesquita, 1995: 119). O centro representaria então a função de um lugar quase sagrado, além de fundador e ancestral. "Considera-se significativo", continua Carvalho da Rocha (idem, 1995: 119), “que, mesmo sob os efeitos de um processo violento de crescimento urbano capaz de descaracterizar a escala humana de sua paisagem, em razão da construção de perimetrais, radiais e viadutos, a cidade de Porto Alegre e seus habitantes gravitem ainda em torno de sua antiga área central”.

Assim, num primeiro período de coleta de materiais empíricos, de elaboração das mais tenras impressões interpretativas e de confecção dos primeiros arranjos metodológicos, pareceu-nos sensato restringir ao centro da cidade - espaço histórica e qualitativamente representativo, como supomos - nosso terreno de trabalho.

\footnotetext{
${ }^{6}$ Ao que consta, Balzac teria dito certa vez que "não se pode pretender ter visto realmente algo antes de tê-lo fotografado". Verídica ou não, a afirmação serve para atribuir mais solidez (retórica, que seja) aos nossos investimentos metodológicos e à exploração de sínteses descritivas entre materiais textuais e fotográficos.
} 


\section{Algumas observações}

Desde já, faz-se necessário também o reconhecimento de que os objetos empíricos que reunimos como subsídio fundamental (e fundamentador) da reflexão não se agrupam, cômoda e pacificamente, de forma límpida ou indiscutível, sob a terminologia que viemos empregando até agora. Expressões como "retóricas expressivas da comunicação visual" ou mesmo a expressão "assinaturas urbanas", estampada solenemente já no título desse artigo, têm valor apenas aproximativo e provisório, pois não nos dão tamanha precisão vocabular nem tamanho poder indicativo. Ou seja: as paisagens e os cenários urbanos policodificados que pretendemos problematizar em seguida (via registros fotográficos) estariam à espera de um batismo conceitual mais apropriado.

No momento, parece-nos sugestivo que a pesquisadora gaúcha Lara Espinosa (2002), em texto recém colocado em circulação, tenha se referido ao que chama de 'compósitos intensivos da comunicação urbana'. Para ela (ESPINOSA, 2002), tratam-se de unidades ou pontos urbanos (manchas urbanas, se pudéssemos conceber a cidade como uma tela cravejada de diferentes tintas, tonalidades e texturas) carregados de uma heterogeneidade alarmante de signos gráficos, textuais e visuais. Além deste hibridismo significante, com franca ascendência das linguagens visuais sobre as demais, registre-se também o traço barroco e a saturação estético-sensorial com os quais resultam cada compósito.

Em nosso caso, mais do que as caracterizações já feitas por Espinosa (unidades de heterogeneidade e excessividade discursivas), é importante considerar também - como elemento ou critério definidor de nossos materiais empíricos, nossas 'linguagens vivas' - a ocorrência de uma 'disputa cruzada' pela atenção do sujeito metropolitano. Internamente, portanto, se as tomarmos como unidades sígnicas destacáveis, tais codificações urbanas irão se instituir quase na anulação mútua dos diversos regimes sígnicos ali justapostos. $\mathrm{O}$ excesso barroco estaria a implicar também algum 'ruído comunicacional' (para não o qualificarmos pejorativamente como 'poluição visual'). Em certos momentos, este 'ruído' pode indicar um ato deliberado de intervenção, de 'contra-comunicação' ou de negação da mensagem prévia, tida como hegemônica naquele contexto específico. Assim, o que funda (ou contribui para fundar) nossos mestiços textos urbanos é uma tensão e um carregamento semióticos. Essa disputa essencial, materializada na superfície significante da cidade, passa a ser lida como disputa política pelo espaço público. 
Dito isto, nada melhor do que a exposição de alguns casos concretos para que a idéia (aqui perseguida) e o conceito operacional (aqui em gestação), bem como nossa problemática de fundo, possam então se elucidar.

Fig. A

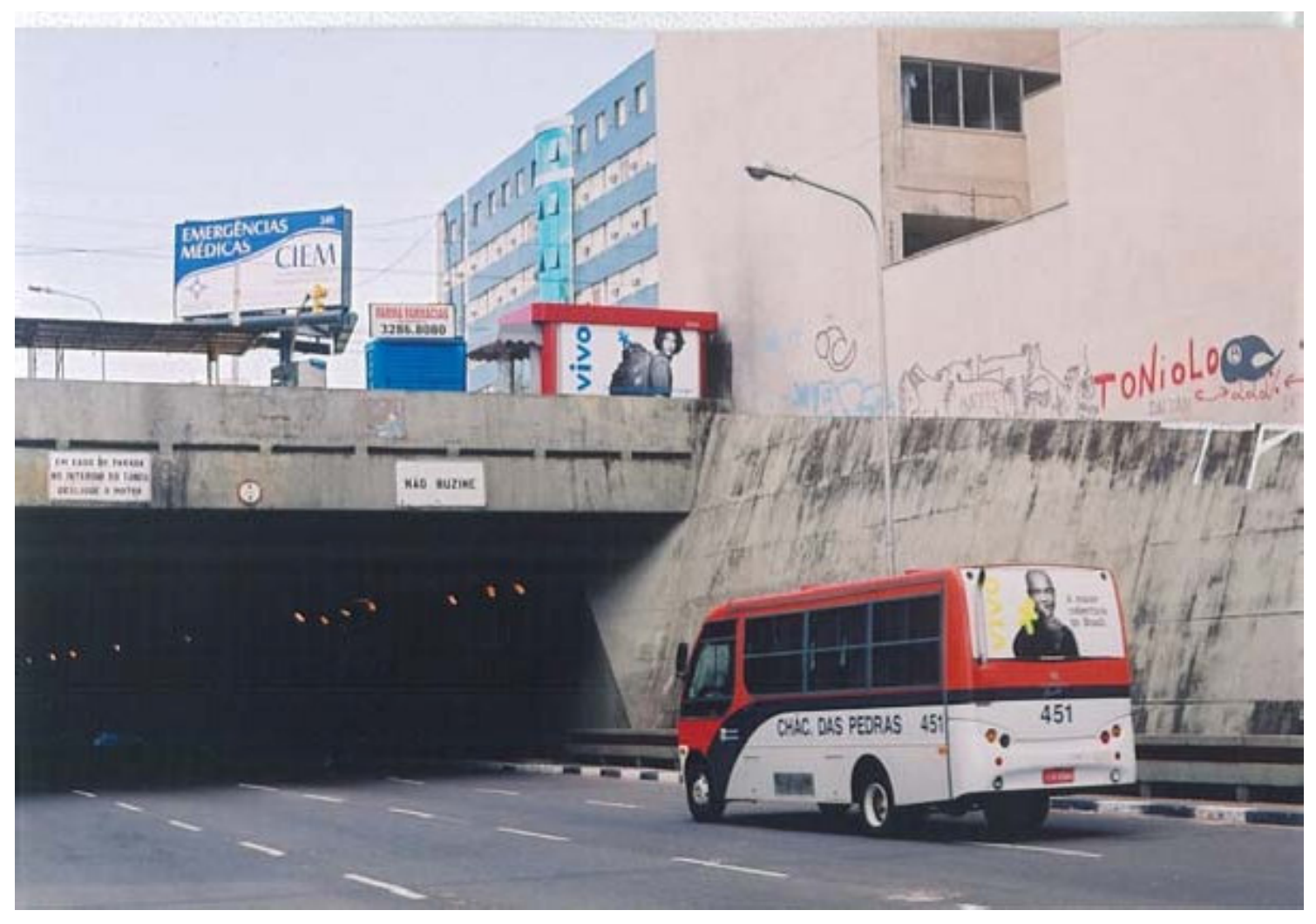


Várias inscrições povoam a paisagem. A princípio, poderíamos agrupá-las em inscrições móveis (o busdoor da Vivo Celular) e fixas: os letreiros - "Emergências médicas", "Farma Farmácias" -, as indicações de trânsito - "Em caso de parada no interior do túnel, desligue o motor", "Não buzine" -, as pichações e os grafites. Estes últimos, por sinal, não aparecem tão destacadamente na fotografia, embora assim ocupem e delimitem a margem do fluxo automobilístico. Para avançarmos em nossa taxonomia, para deixarmos esboçado um rigoroso catálogo dessas 'linguagens vivas da comunicação urbana', deveríamos mensurar inclusive a temporalidade dos códigos. Assim, poderíamos supor a existência de códigos de temporalidade regular, em oposição, claro, àqueles irregulares. Ou teríamos códigos de temporalidade cíclica e outros cuja instauração é condicionada por uma combinação de agendas que sempre lhes excedem (agendas macro-políticas ou mesmo midiáticas)?

Revolvendo - e revelando, cabe notar - o inconsciente ótico metropolitano (seus lapsus linguae), a imagem fotográfica registra também uma efêmera sinfonia sígnica, uma estranha orquestração de códigos. São essas fortuitas montagens urbanas que permitem a reincidência da campanha da Vivo Celular (no micro-ônibus e na banca de revistas, situada na Av. Independência, sobre o viaduto). Entretanto, poderia ter ocorrido ali um curioso confronto de marcas: marcas concorrentes num embate irônico, num entre-choque mutuamente diluidor. Assim como bem poderia ter acontecido, mais singularmente, na boca do túnel, um povoamento maior de inscrições móveis: a ocupação da cidade como denso e concorrido espaço publicitário. Diante de tantos apelos visuais, como se comporta então o olho do sujeito ao volante? Na dança caótica dos signos urbanos, como se dá a geo-estratégia do olhar?

De qualquer forma, esta é uma das primeiras paisagens - 'paisagens retóricas', poderíamos dizer - que se oferece àquele que chega em Porto Alegre, que tenha cruzado a BR-116 em direção à rodoviária da cidade. Ao estrangeiro e ao visitante, dentre todas aquelas inscrições, por certo uma passará desapercebida ou então soará particularmente incompreensível: 'Toniolo'. Entretanto, dias depois, ele já terá se deparado com ela outras tantas vezes. Para o jornalista Marcello Campos ${ }^{7}$, por exemplo, é praticamente impossível percorrer as ruas da capital gaúcha sem nos defrontarmos com o autógrafo - ‘Toniolo' - em muros, monumentos e prédios públicos (Fig. B). Seria essa uma das assinaturas mais pessoais e intransferíveis da cidade?

\footnotetext{
${ }^{7}$ Segundo Campos, o autor das pichações é o escrivão de polícia aposentado Sérgio Toniolo, 58 anos. Nas duas últimas décadas, ele teria gasto 3 mil tubos de spray, distribuindo cerca de 70 mil pichações pela cidade. Maiores detalhes encontram-se em http://planeta.terra.com.br/arte/359/marcelloc02.htm.
} 
Fig. B

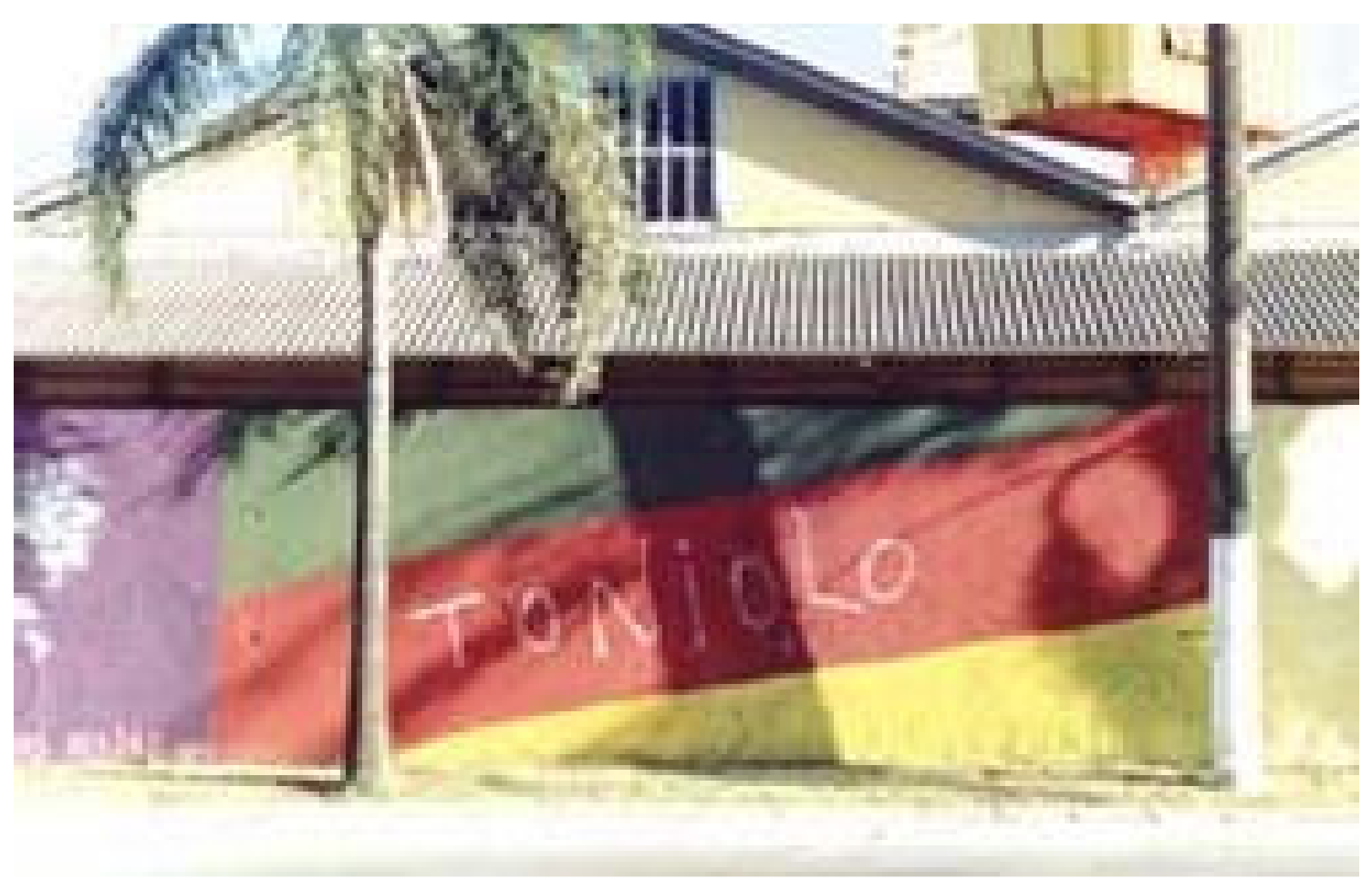

Fig. C

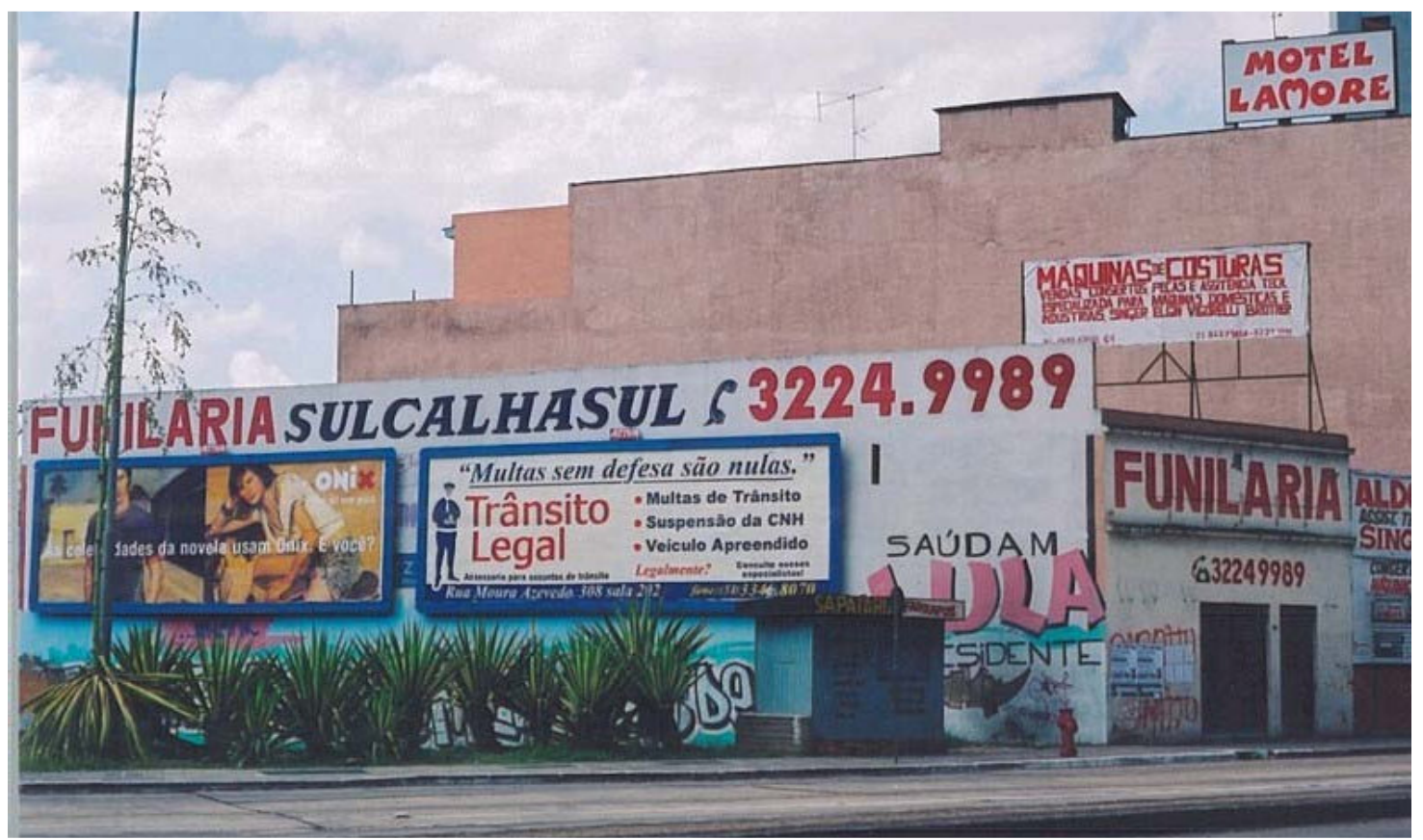


"Motel Lamore", "Máquinas de costuras", "Funilaria Sulcalhasul Fone 32249989", "Trânsito Legal", "Saúdam Lula presidente". Ao longo da Av. Farrapos, muitos são os trechos onde se justapõem dizeres de toda ordem. Nesta imagem específica chama atenção o caráter artesanal e/ou a precariedade no acabamento das fachadas. Somada aos outdoors, à vegetação opulenta e à modestíssima banca de chaveiro ali instalada, a profusão de letras, num vermelho insistente, satura o cenário de tal forma que cada mensagem e cada anúncio singulares resultam contaminados pelo entorno. Os sentidos específicos, sempre fugidios, donos de um já precário e confuso poder indicativo, são esvaziados e reconfigurados numa prosa única, mais significante por sua desordenada plasticidade. Se entendermos a cidade como uma convidativa e irrecusável página em branco, à espera dos traços que possam sujá-la - a palavra é preenchimento e mácula -, uma questão, enfim, seria possível: existe algo mais democrático do que um muro?

Fig. D

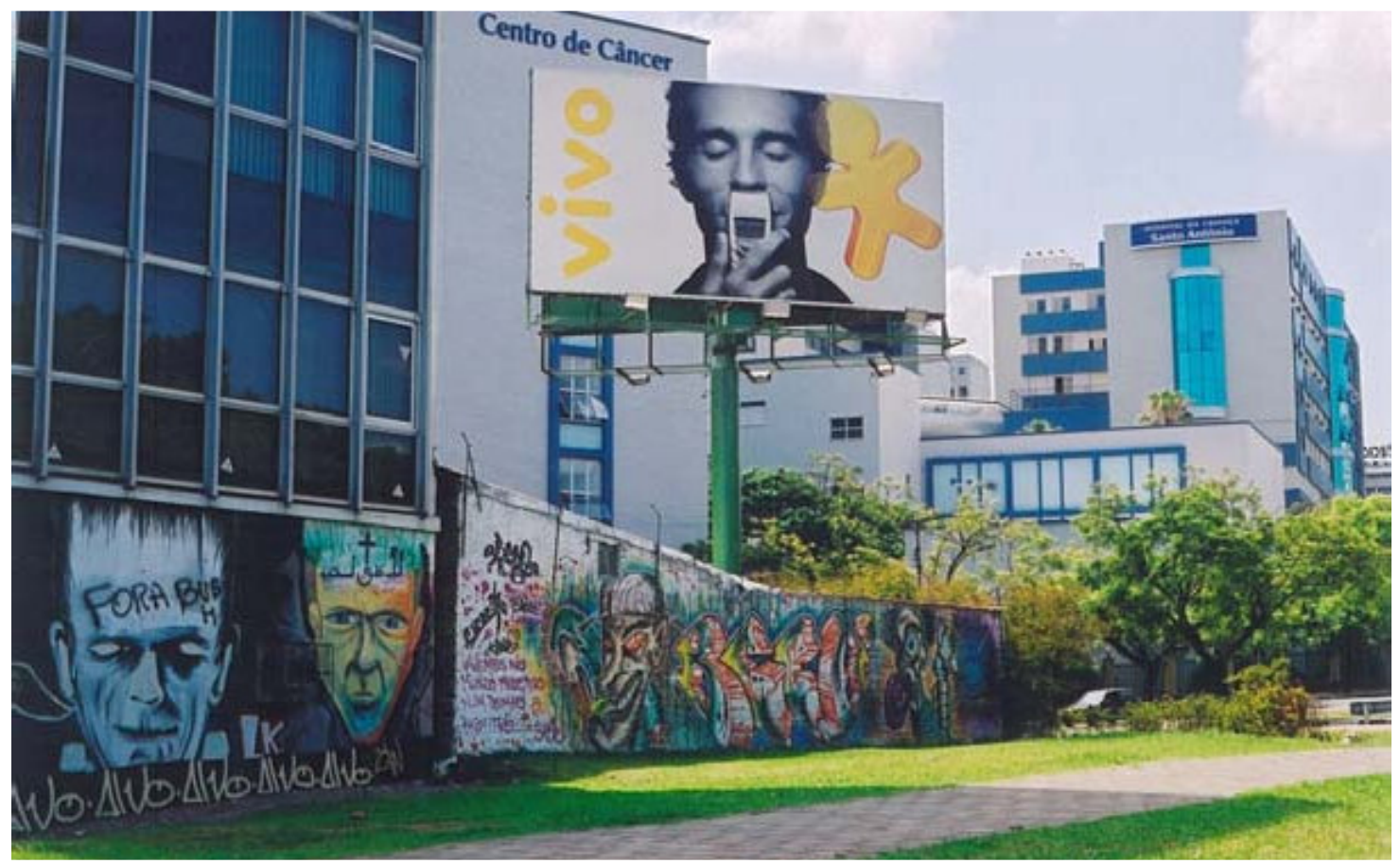


Hoje, tamanha a frequiência com que é citada, a formulação de Marc Augé (1994) sobre os 'não-lugares' (e sobre uma 'etnologia da solidão' que daí decorreria) alçou-se à condição de um clássico (quase um mantra) na pesquisa sócio-antropológica-comunicacional. Entretanto, se nos despirmos de uma certa nostalgia pelos tradicionais lugares antropológicos (lugares relacionais e históricos: lugares da memória), não poderíamos redescobrir a força simbólica e gregária de certos espaços? Trataria-se então de re-encontrar ou re-aprender a ver lugares que possam oferecer uma contra-face qualquer à impessoalidade administrativa e à assepsia identitária com as quais a cultura global pretende instaurar-se. Conseguiríamos reconfigurar a reação fenomênica-situada que pudesse impor à ordem cultural hegemônica, e ao 'turbo-capitalismo', como fala Sodré, uma revisão condizente com a realidade, com a nossa realidade? Ao articular o imaginário tecnológico contemporâneo (o outdoor da Vivo Celular) e o imaginário mítico dos Frankensteins estilizados - ao todo, são três rostos cravados na paisagem -, ao articular ainda a força loquaz da cultura hip-hop (os grafites e suas cores poéticas) e o brado mínimo do descontentamento político ("Fora Bush"), cenários como este não estariam a metaforizar novas linhas para o entendimento dos micro-processos de resistência que ainda fazem das cidades o terreno dos jogos e das expressões vitais, da sobrevivência, enfim, da coletividade?

\section{REFERÊNCIAS}

AUGÉ, Marc. Não-Lugares. Introdução a uma antropologia da supermodernidade. Campinas: Papirus, 1994.

BENJAMIN, Walter. Magia e Técnica, Arte e Política. Ensaios sobre literatura e história da cultura. Obras Escolhidas. $3^{\text {a }}$ ed. São Paulo: Brasiliense, 1987a.

BENJAMIN, Walter. . Rua de Mão Única. Obras Escolhidas II. $5^{\text {a }}$ ed. São Paulo: Brasiliense, 1987b.

BENJAMIN, Walter. . Charles Baudelaire. Um lírico no auge do capitalismo. $1^{\mathrm{a}}$ ed. Obras Escolhidas III. São Paulo: Brasiliense, 1989a.

BERMAN, Marshall. Tudo Que é Sólido Desmancha no Ar. A aventura da modernidade. São Paulo: Cia. das Letras, 1986.

CANCLINI, Néstor García. A Globalização Imaginada. São Paulo: Iluminuras, 2003.

CANEVACCI, Massimo. A Cidade Polifônica. Ensaio sobre a antropologia da comunicação urbana. $2^{a}$ ed. São Paulo: Studio Nobel, 1997, $2^{\mathrm{a}}$ ed.

CASTELLS, Manuel. La Cuestión Urbana. $1^{\text {a }}$ ed. Barcelona - Madri: Siglo XXI, 1979 (tradução brasileira: A Questão Urbana. São Paulo: Ed. Paz e Terra, 2000).

CERTEAU, Michel de. A Invenção do Cotidiano. 1. Artes de fazer. $5^{\mathrm{a}}$ ed. Petrópolis: Vozes, 2000.

CLIFFORD, James. A Experiência Etnográfica. Antropologia e Literatura no século XX. Rio de Janeiro: Ed. UFRJ, 1998.

COULON, Alain. A Escola de Chicago. Campinas: Papirus, 1995. 
DOWNING, John. Mídia Radical. Rebeldia nas comunicações e nos movimentos sociais. São Paulo: Ed. SENAC, 2002.

ECKERT, Cornelia; ROCHA, Ana Luiza Carvalho da. Etnografia na rua e câmera na mão. Revista Studium, n.08, UNICAMP, Campinas - SP, verão/2002. Disponível em $<$ http://www.studium.iar.unicamp.br/oito/index.html>. Acessado em 26/01/04.

ESPINOSA, Lara. Estudo do uso intensivo da comunicação visual no meio urbano como matriz para novas linguagens visuais. Trabalho apresentado no NP Publicidade, Propaganda e Marketing, no XXV Congresso Brasileiro de Ciências da Comunicação (INTERCOM), realizado em Salvador - BA, de 01 a 05 de setembro de 2002. Anais do Congresso, 14p.

FERRARA, Lucrécia D’Aléssio. Design em Espaços. São Paulo: Edições Rosari, 2002.

KLEIN, Naomi. Sem Logo. A tirania das marcas em um planeta vendido. São Paulo; Rio de Janeiro: Editora Record, 2003.

MAGNANI, José Guilherme Cantor. Quando o campo é a cidade: fazendo antropologia na metrópole. in: MAGNANI, José Guilherme Cantor; TORRES, Lílian de Lucca (orgs.). Na Metrópole. Textos de antropologia urbana. São Paulo: EDUSP, 2000, p.1253.

ROCHA, Ana Luiza Carvalho da. A irracionalidade do belo e a estética urbana no Brasil. in: BRANDÃO, Carlos Rodrigues; MESQUITA, Zilá. Territórios do Cotidiano. Uma introdução a novos olhares e experiências. Porto Alegre; Santa Cruz do Sul: Ed.UFRGS; Ed. UNISC, 1995, p.110-129.

SEVCENKO, Nicolau. A Corrida para o Século XXI. No loop da montanha-russa. São Paulo: Cia. das Letras, 2001 (Coleção Virando Séculos, 07).

SIMMEL, Georg. A metrópole e a vida mental. in: VELHO, Otávio. O Fenômeno Urbano. Rio de Janeiro: Ed. Zahar, 1979.

SODRÉ, Muniz. Antropológica do Espelho. Uma teoria da comunicação linear e em rede. Petrópolis - RJ: Vozes, 2002. 